\title{
Developing Competency Test Instrument of Senior High School Physical Educator
}

\author{
Masrun*, Yanuar Kiram, Gusril, Sayuti Syahara \\ Faculty of Sport Science, Padang State University, Padang, 25571, West Sumatera, Indonesia
}

Received July 21, 2020; Revised August 26, 2020; Accepted September 29, 2020

\section{Cite This Paper in the following Citation Styles}

(a):[1]Masrun, Yanuar Kiram, Gusril, Sayuti Syahara , "Developing Competency Test Instrument of Senior High School Physical Educator," Universal Journal of Educational Research, Vol. 8, No. 11, pp. 5395 - 5404, 2020. DOI: 10.13189/ujer.2020.081142.

(b):Masrun, YanuarKiram, Gusril, SayutiSyahara (2020). Developing Competency Test Instrument of Senior High School Physical Educator. Universal Journal of Educational Research, 8(11), 5395-5304. DOI: 10.13189/ujer.2020.081142.

Copyright $\odot 2020$ byauthors, allrightsreserved.Authorsagreethatthisarticleremainspermanentlyopenaccessunderthetermsof theCreativeCommonsAttributionLicense4.0InternationalLicense

\begin{abstract}
The main objective of this study was to produce an instrument of competency test for High School Physical Educator, which was validated empirically. At present, researchers have not yet found an instrument that tests the competency of teachers involving 4 competencies, particularly in Indonesia. This study was a research and development design following the form of procedural models, which are steps that must be followed to produce standard instrument products. The steps were: (1) Finding Potential Problems, (2) Information gathering, (3) Product Design, (4) Design Validation, (5) Design Improvement, (6). Product Trial, (7). Product Revision, (8). Usage Tests, (9) Product Revisions, (10) Mass Product Manufacturing. The test subjects in this study were high school teachers in Padang and FIK UNP alumni amounting to 323 people. Sampling technique used was purposive sampling. Based on data taken from the field of secondary education in Padang City Education Office, the number of high school teachers in Padang was about 146 people, and FIK alumni were177 person. In the first phase, a limited trial was carried out on 30 samples of the total population. The second phase was tested on 293 people. The standardization process is carried out by carrying out various tests, namely: (1) Validity test, (2) Reliability Counters, (3) Difficulty level test, (4) Different grain power test, (5) Practicality test, (6) effectiveness test. All data were analyzed by using IBM SPSS software and significance level was $\mathrm{p}<0.05$. Based on the research processes and procedures carried out, a standardized instrument can be used to test the four Physical Educators
\end{abstract}

competencies, namely Pedagogic competence, Professional Competency, Personality competence, and Social competence.

Keywords Competencies, Physical Educators, Senior High School

\section{Introduction}

Teacher education reformation throughout the world has been oriented towards functional teacher preparation, which aims to develop the competencies they need in practice (Pantić\&Wubbels, 2010). Teaching and learning activities are processes that have a level of complexity. Various attempts have been made to increase effectiveness, in a deep understanding of the nature of teacher work (Ovens, Hopper, \& Butler, 2013). Therefore, teacher competency testing needs to be done.

In this study, teacher competency is defined as a set of personal characteristics, knowledge, skills and integrated attitudes needed for effective performance in various teaching contexts (Arifin, Rasdi, Anuar, \& Omar, 2018; Stoof, Martens, Van Merriënboer, \&Bastiaens , 2002; Tigelaar, Dolmans, Wolfhagen, \& Van Der Vleuten, 2004). Performance theory is a basic concept for competence which believes maximum performance is to occur when people's abilities are in accordance with the needs of the job (Boyatzis, 1982). Where, one's abilities 
are explained by personal philosophies, visions, values; knowledge; competence; life and career stages; style and interests (Arifin et al., 2018).

According to the concept of competency, teacher competency is divided into four domains, those are; (1) pedagogical knowledge (2) knowledge content of professional subject matter, (3) personality knowledge, (4) social knowledge (Gudmundsdottir\&Shulman, 1987). The first domain in the measurement framework, teaching competence requires the ability of teachers to integrate theory and practice in classroom activities (Diep\& Hartmann, 2016; Salyakhova\&Valeeva, 2015). In this case, physical educator must be able to design teaching and learning goals (Loewenberg Ball, Thames, \& Phelps, 2008). Considering this, physical education teachers need to use different teaching techniques and use practical approaches to reflect teaching objectives.

Professional competence ensures that physical education teachers master knowledge content with the latest information needed by students (Grollmann, 2008). This professional competence, determines broad professional knowledge, and has skills (Education \& International, 2015). The third domain that represents the work of physical education teachers is personality competence. This domain is a picture of self, ethics, and personal goals are personal traits that can increase the level of competence of teachers in education services for effective performance (Yusof, Roddin, \&Awang, 2015).

The concept of social competence is the last part that presents conceptualization and assessment in learning (Waters \&Sroufe, 1983). To provide knowledge to students, teachers should have communication skill (Oluwasola, 2014). This ability helps teachers to make effective communication with students (HasrilAmiruddin, 2015). The four domains of teacher competence, it is important to make an instrument to test especially in the physical education teacher profession (Spöttl\& Becker, 2016). This, aims to see the strengths and weaknesses of individual teachers in certain areas of competence (Aqtash et al., 2017; Cumberland, Herd, Alagaraja, \&Kerrick, 2016; Greenstein, 2012).

However, previous studies have not shown empirical studies related to the measurement instruments for teacher competency testing as an important domain of the teaching profession. Until now there is still limited literature related to teacher competency tests. Where the competency aspects tested in the UKG are "pedagogical competence and professional competence in the cognitive realm" (Permendikbud No. 57 of 2012 Teacher
Competency Test). This has not yet tested the four domains of teacher competence in the framework of education. Therefore, the main objective of this article is to develop a teacher competency test instrument to measure the four competency domains for Physical Education teachers in Indonesia.

\section{Methodology}

\section{Research Design}

This study used research and development design. In this research, the development model used was procedural models, involving several steps that must be followed to produce standard instrument products. The development procedures carried out include ten steps, namely: (1) Finding Potential Problems, (2) Gathering information, (3) Product Design, (4) Design Validation, (5) Design Improvement, (6) Product Trial, (7) ) Product Revision, (8) Usage Trial, (9) Product Revision, (10) Mass Production.

\section{Sampling Technique}

This research involved high school physical educator in Padang and alumni of FIK UNP, amounting to 323 people. Sampling was done by using purposive sampling. Based on data taken from the field of secondary education in Padang Secondary Education Affair, the number of high school teachers in Padang, both teachers who are civil servants (PNS), foundation teachers and honorarium teachers are 146 people, and FIK alumni taken as subject of research are 177 people. In the first phase, a limited trial was carried out on 30 of the total population. The second phase was tested on 293 people from the total population.

\section{Development model}

Having known that the teacher competency test conducted was still not complete and complex, the researcher compiles the teacher competency test instrument based on four domains namely (1) pedagogical competence, (2) professional competence, (3) personality competence, and (4) social competence. It was aimed to reflect current needs in the teaching profession. This article focuses on aspects of developing a teacher competency test instrument (UKG), which is a conceptual model of developing that instrument. 


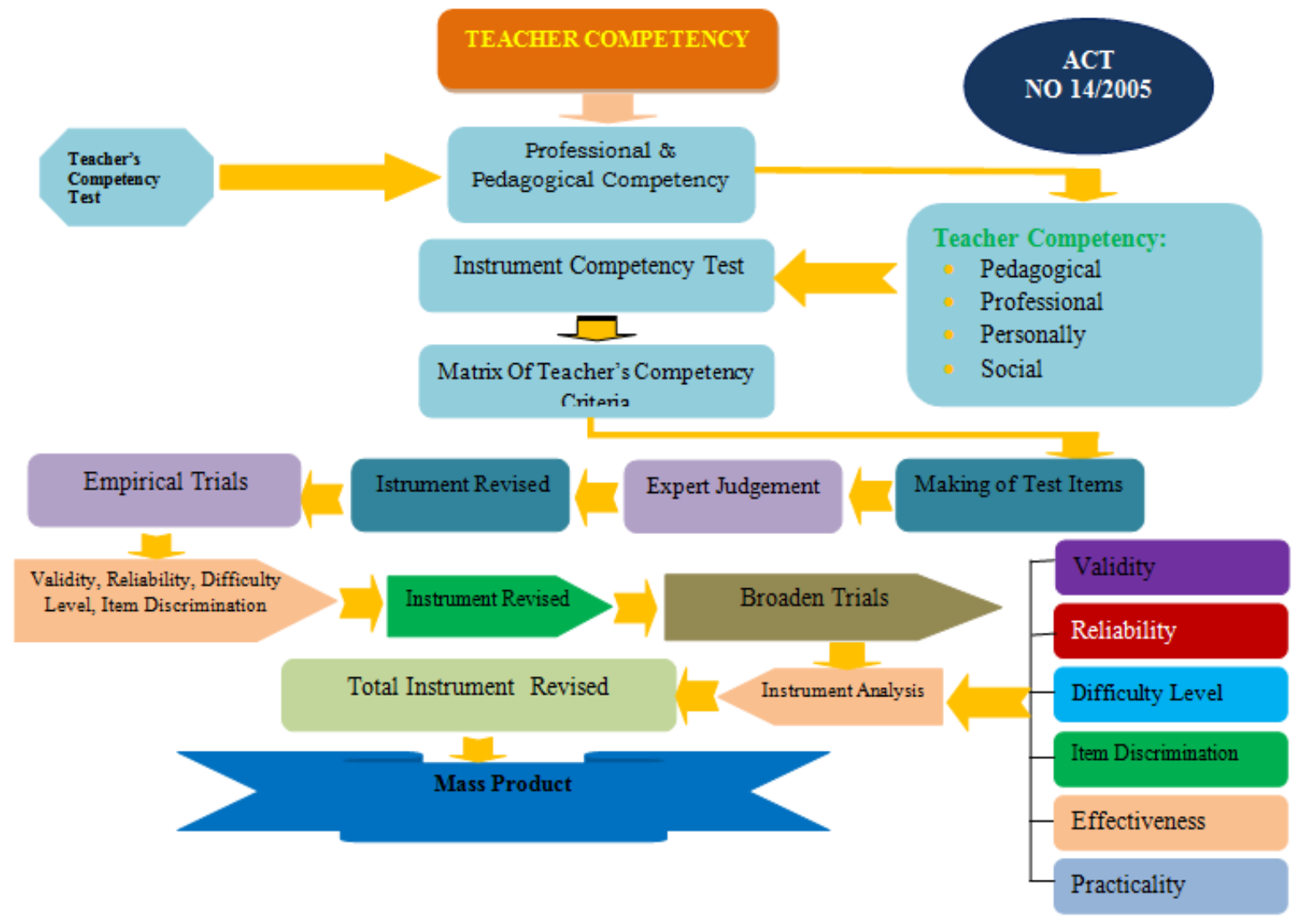

Figure 1. Steps in Producing Standardized Physical Educator Competency Test Instruments

\section{Data analysis}

Descriptive statistical analysis aims to describe the general level of assessment of the instruments compiled. Furthermore, the construct validity test was determined by an analysis of the average scores of five expert judgments. The analysis is done by looking at the average difference between the five expert judgments. The difficulty of an item is determined by comparing the passing rate among the five expert judgments for each item through chi-square analysis. Internal reliability is determined by item-total correlation (ITC) using the Pearson moment product correlation coefficient. ITC $\geq 0.15$ is considered acceptable because it examines the extent to which all test questions on a test measure a single construction (Varma, 2006). Internal consistency is measured through Cronbach's alpha (Nunnally, 1978). Cronbach's Alfa ranging from 0.6 to 0.7 is considered to show acceptable internal consistency, 0.7 to 0.9 good internal consistency> 0.90 as excellent internal consistency (George, D., \&Mallery, George, \&Mallery, 2003). Furthermore, to create a standard instrument, the steps were then proceeded by:

1. Test the validity of items, which relate to how far the measuring instrument is able to measure what should be measured.

2. Test the reliability of items, which is related to trust issues.
3. Test the level of difficulty items, to see the proportion of test participants answer correctly to the test items.

4. Test of item discrimination. It is a test that seeks to show the level of ability of the test items to distinguish groups of high achievers (upper group) from groups of low achievers (lower groups) among test takers.

5. Test the practicality of the instrument, which relates to how far the practicality of the use of the instrument made.

6. Test the effectiveness of the instrument, which is related to the extent of the efficiency of the use of the instrument made (Cury, Arias Astray, \& Palacios Gómez, 2019; Kane, 2013).

All data were analyzed by using IBM SPSS software. Significance was determined at the level of $\mathrm{p}<0.05$.

\section{Result}

Descriptive statistical analysis aims to describe the general level of assessment of the instruments compiled. Furthermore, the construct validity test was determined by an analysis of the average scores of five expert judgments. The analysis is done by looking at the average difference between the five expert judgments. The difficulty of an 
item is determined by comparing the passing rate among the five expert judgments for each item through chi-square analysis. Internal reliability is determined by item-total correlation (ITC) using the Pearson moment product correlation coefficient. ITC $\geq 0.15$ is considered acceptable because it examines the extent to which all test questions on a test measure a single construction (Varma, 2006). Internal consistency is measured through Cronbach's alpha (Nunnally, 1978). Cronbach's Alfa ranging from 0.6 to 0.7 is considered to show acceptable internal consistency, 0.7 to 0.9 good internal consistency $>0.90$ as excellent internal consistency (George, D., \&Mallery, George, \&Mallery, 2003). Furthermore, to create a standard instrument, the steps were then proceeded by:

1) Test the validity of items, which relate to how far the measuring instrument is able to measure what should be measured.

2) Test the reliability of items, which is related to trust issues.

3) Test the level of difficulty items, to see the proportion of test participants answer correctly to the test items.

4) Test of item discrimination. It is a test that seeks to show the level of ability of the test items to distinguish groups of high achievers (upper group) from groups of low achievers (lower groups) among test takers.

5) Test the practicality of the instrument, which relates to how far the practicality of the use of the instrument made.

6) Test the effectiveness of the instrument, which is related to the extent of the efficiency of the use of the instrument made (Cury, Arias Astray, \& Palacios Gómez, 2019; Kane, 2013).

All data were analyzed by using IBM SPSS software.
Significance was determined at the level of $\mathrm{p}<0.05$.

Table 1. The construct validity test

\begin{tabular}{ccc}
\hline Appropriateness & $\begin{array}{c}\text { Inter rater Validity } \\
\text { (median) }\end{array}$ & Note \\
\hline Core Competency Dimension & 8 & Valid \\
Core Competency and Indicator & 8 & Valid \\
Indicator and items & 8 & Valid \\
\hline
\end{tabular}

The table above shows the construct validity test conducted by experts having a median value (1) 8 for conformity dimensions with core competencies being in good categories, (2) 8 for core competency suitability with indicators being in good categories, (3) 8 for indicator conformity items are in good categories.

Table 2. Expert Judgement of the Reliability of Physical Education Teacher Competency Instruments

\begin{tabular}{ccc}
\hline Appropriateness & $\begin{array}{c}\text { Inter rater } \\
\text { Reliability }\end{array}$ & Note \\
\hline Core Competency Dimension & 0,753 & Reliable \\
Core Competency and Indicator & 0,819 & Reliable \\
Indicator and items & 0,816 & Reliable \\
\hline
\end{tabular}

$p>0,90$

The table above shows the results of calculations using SPSS showing that the competency of Physical Education teachers in terms of pedagogically, personally, socially and professionally in Cronbach's Alpha reliable coefficient are (1) 0.753 for conformity between dimensions and core competencies in the good category, (2) 0.819 for conformity between core competencies and indicators are in the good category, (3) 0.816 for suitability between indicators and items in the good category. 
Table 3. Results of Analysis of Competency Test Instruments for Physical Education Teachers (Limited Trials)

\begin{tabular}{|c|c|c|c|c|c|}
\hline No & Competency & Frequency & Percentage & Reliability Coefficient & Conclusion \\
\hline \multirow[t]{17}{*}{1} & Pedagogic & & & & \\
\hline & Validity Test & & & & \\
\hline & Valid & 54 & $90 \%$ & & \multirow{3}{*}{54 items are valid } \\
\hline & Not Valid & 6 & $10 \%$ & & \\
\hline & $\Sigma$ & 60 & $100 \%$ & & \\
\hline & Reliable & & & 0.989 & \\
\hline & Level of Difficulty & & & & \\
\hline & Difficult & 5 & $8.33 \%$ & & Repaired \\
\hline & Average & 46 & $76.67 \%$ & & \\
\hline & Low & 9 & $15.00 \%$ & & \\
\hline & $\Sigma$ & 60 & $100 \%$ & & \\
\hline & Item Discrimination & & & & Repaired \\
\hline & Very Good & 55 & $91.67 \%$ & & \\
\hline & Good & 2 & $3.33 \%$ & & \\
\hline & Fair enough & 1 & $1.67 \%$ & & \\
\hline & Poor & 2 & $3.33 \%$ & & \\
\hline & $\Sigma$ & 60 & $100 \%$ & & \\
\hline \multirow[t]{17}{*}{2} & Professional & & & & \\
\hline & Validity Test & & & & \\
\hline & Valid & 56 & $93.33 \%$ & & \multirow{3}{*}{56 items are } \\
\hline & Not Valid & 4 & $6.67 \%$ & & \\
\hline & $\Sigma$ & 60 & $100 \%$ & & \\
\hline & Reliable & & & 0.991 & \\
\hline & Level of Difficulty & & & & repaired \\
\hline & Difficult & 3 & $5 \%$ & & \\
\hline & Average & 42 & $70 \%$ & & \\
\hline & Low & 15 & $25 \%$ & & \\
\hline & $\Sigma$ & 60 & $100 \%$ & & \\
\hline & Item Discrimination & & & & Repaired \\
\hline & Very Good & 55 & $91.67 \%$ & & \\
\hline & Good & 1 & $1.67 \%$ & & \\
\hline & Fair enough & 3 & $5.00 \%$ & & \\
\hline & Poor & 1 & $1.67 \%$ & & \\
\hline & $\Sigma$ & 60 & $100 \%$ & & \\
\hline \multirow[t]{6}{*}{3} & Personality & & & & \\
\hline & Validity Test & & & & \\
\hline & Valid & 44 & $91.67 \%$ & & \multirow{3}{*}{44 items are valid } \\
\hline & Not Valid & 4 & $8.33 \%$ & & \\
\hline & $\Sigma$ & 48 & $100 \%$ & & \\
\hline & Reliability & & & 0.886 & \\
\hline \multirow[t]{6}{*}{4} & Social & & & & \\
\hline & Validity Test & & & & \\
\hline & Valid & 29 & $90.63 \%$ & & \multirow{3}{*}{44 items are } \\
\hline & Not Valid & 3 & $9.38 \%$ & & \\
\hline & $\Sigma$ & 32 & $100 \%$ & & \\
\hline & Reliability & & & 0.905 & \\
\hline
\end{tabular}

The table above shows that, (1) pedagogical competencies have 54 valid questions, (2) provisional competencies have 56 valid questions, (3) personality competencies have 44 valid statement items, and (4) social competencies have 44 valid statement items. Figure 2 shows the results of the analysis of limited trials can be seen in the following chart 1. 


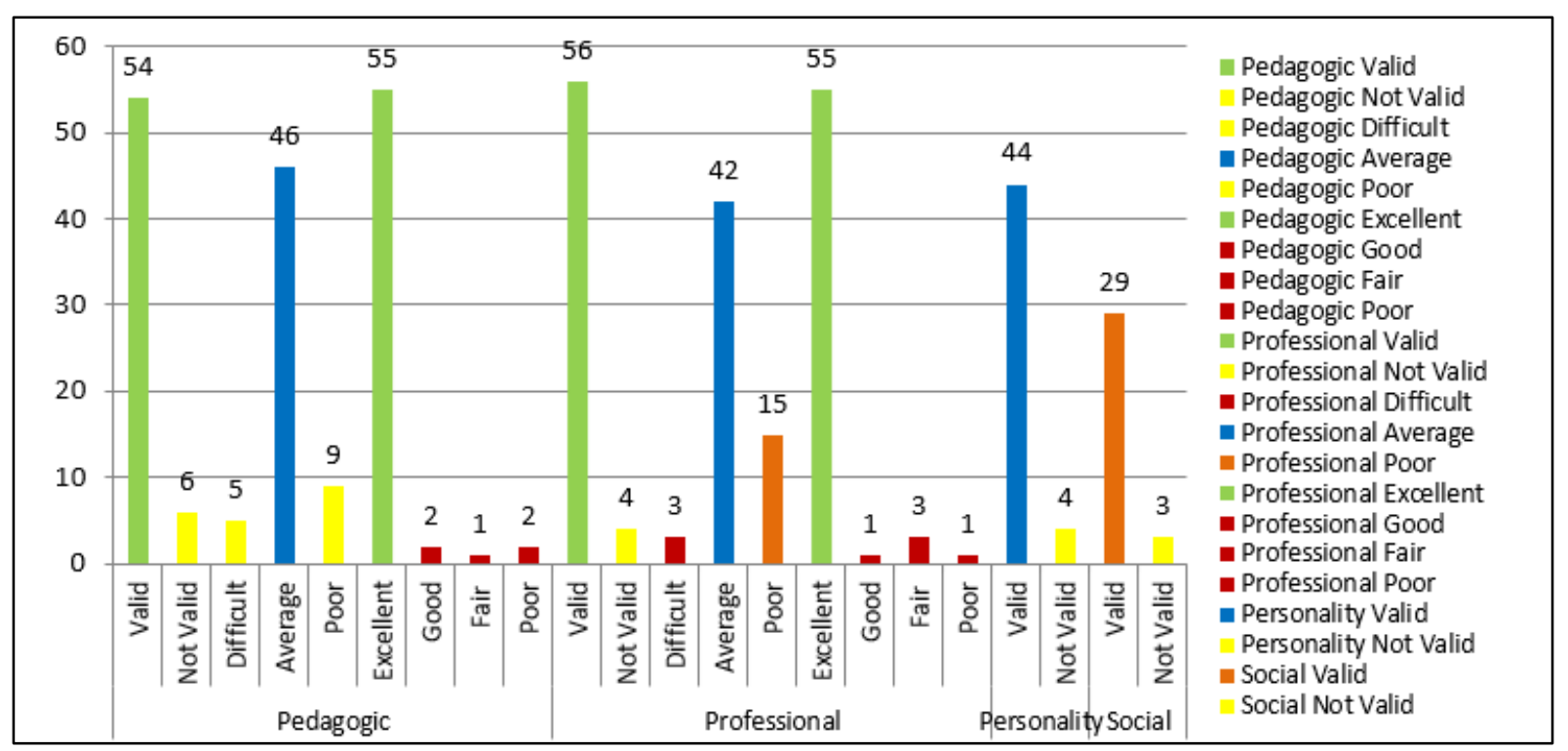

Figure 2. Histogram of Physical Education Teacher Competency Test Instruments (Competency Trials)

Table 4. Results of Analysis of Competency Test Instruments for Physical Education Teachers (Broaden Trials)

\begin{tabular}{|c|c|c|c|c|c|}
\hline No & Competency & Frequency & Percentage & Reliability Coefficient & Conclusion \\
\hline \multirow[t]{17}{*}{1} & Pedagogic & & & & \\
\hline & Validity Test & & & & \multirow{4}{*}{53 items are valid } \\
\hline & Valid & 53 & $98.15 \%$ & & \\
\hline & Not Valid & 1 & $1.85 \%$ & & \\
\hline & $\Sigma$ & 54 & $100 \%$ & & \\
\hline & Reliable & & & 0.949 & \multirow{6}{*}{ Repaired } \\
\hline & Level of Difficulty & & & & \\
\hline & Difficult & 5 & $9.26 \%$ & & \\
\hline & Average & 24 & $44.44 \%$ & & \\
\hline & Low & 25 & $46.30 \%$ & & \\
\hline & $\Sigma$ & 54 & $100 \%$ & & \\
\hline & Item Discrimination & & & & \multirow[t]{6}{*}{ Repaired } \\
\hline & Very Good & 53 & $98.15 \%$ & & \\
\hline & Good & 0 & $0.00 \%$ & & \\
\hline & Fair enough & 1 & $1.85 \%$ & & \\
\hline & Poor & 0 & $0.00 \%$ & & \\
\hline & $\Sigma$ & 54 & $100 \%$ & & \\
\hline \multirow[t]{17}{*}{2} & Professional & & & & \\
\hline & Professional & & & \multirow{11}{*}{0.952} & \multirow{5}{*}{54 items are valid } \\
\hline & Validity Test & 54 & $96.43 \%$ & & \\
\hline & Valid & 2 & $3.57 \%$ & & \\
\hline & Not Valid & 56 & $100 \%$ & & \\
\hline & $\Sigma$ & & & & \\
\hline & Reliable & & & & \multirow[t]{5}{*}{ repaired } \\
\hline & Level of Difficulty & 3 & $5.36 \%$ & & \\
\hline & Difficult & 42 & $75.00 \%$ & & \\
\hline & Average & 11 & $19.64 \%$ & & \\
\hline & Low & 56 & $100 \%$ & & \\
\hline & $\Sigma$ & & & & \multirow[t]{2}{*}{ Repaired } \\
\hline & Item Discrimination & 54 & $96.43 \%$ & & \\
\hline & Very Good & 1 & $1.79 \%$ & & \\
\hline & Good & 1 & $1.79 \%$ & & \\
\hline & Fair enough & 0 & $0.00 \%$ & & \\
\hline & Poor & 56 & $100 \%$ & & \\
\hline
\end{tabular}


Table 4 Continued

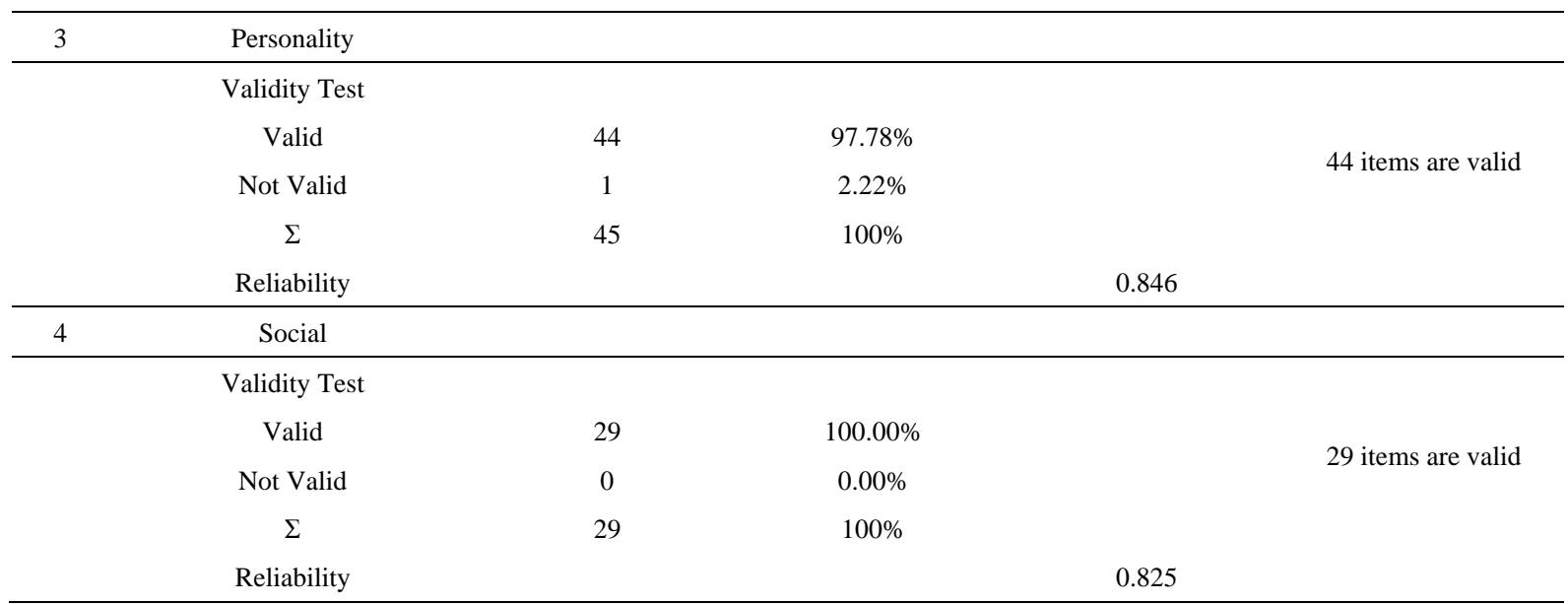

Table 4 shows that, (1) pedagogical competencies have 53 valid questions, (2) provisional competencies have 54 valid questions, (3) personality competencies have 44 valid statement items, and (4) social competencies have 29 valid statement items. Table three of Figure 2 shows the results of the limited trial analysis can be seen in the following chart 1;

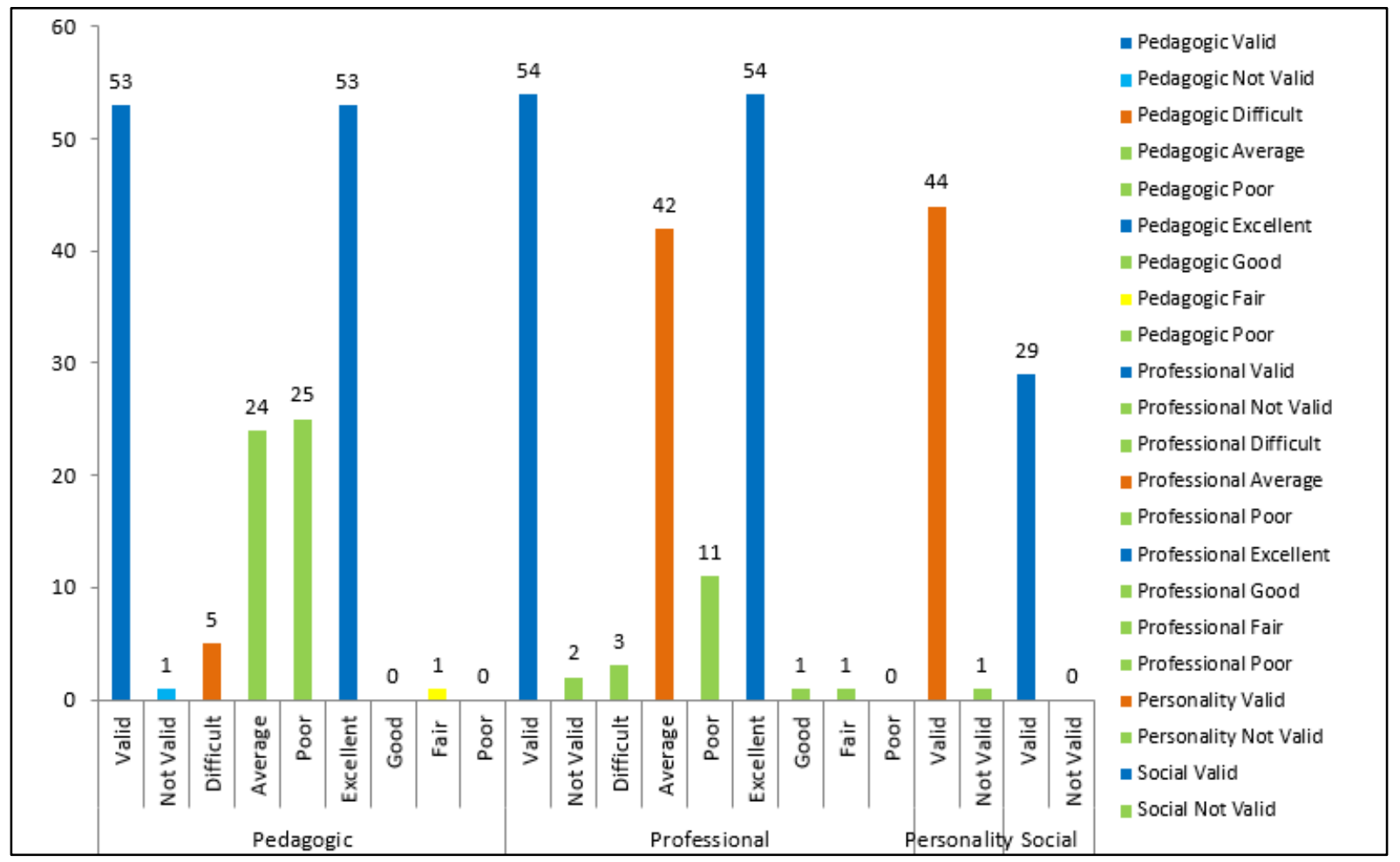

Figure 3. Histogram Analysis of Competency Test Instruments for Physical Education Teachers in Broad Trials

\section{Practicality of Instruments}

Table 5. Frequency Distribution of Practicality (Physicality) Instrument of Competency Test for Physical Education Teachers

\begin{tabular}{cccccc}
\hline Interpretation & Frequency & Percent & Valid Percent & Cumulative Percent & Interprestasi \\
\hline Practical enough & 4 & $13.33 \%$ & 13.333 & 13.333 & 83.333 \\
Practical & 21 & $70.00 \%$ & 70.000 & 100.000 & 85,96 \\
Very Practical & 5 & $16.67 \%$ & 16.667 & & (practical) \\
Missing & 0 & $0.00 \%$ & 13.333 & & \\
Total & 30 & $100 \%$ & & & \\
\hline
\end{tabular}


The practicality value of the Physical Education teacher competency test instruments can be visualized in the following chart;

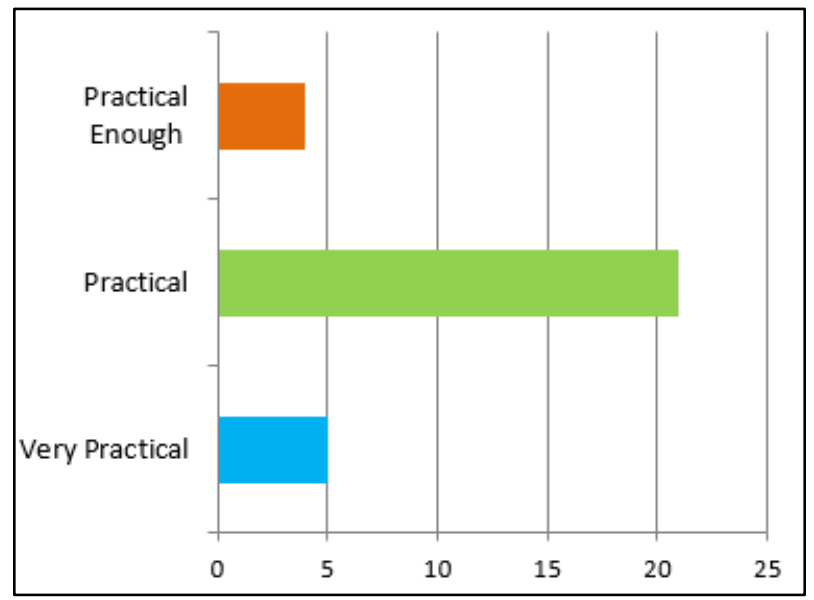

Figure 4. Practicality of Competency Test Instruments for Physical and Physical Education Teachers

The data shown in table 5 above reveals that of the 30 teachers tested (Physical Education teachers) who provided an assessment of practicality of the Physical Education Teacher's Competency Test Instrument, 5 teachers rated with very practical interpretation, 21 teachers assessed with practical interpretation, and 3 teachers rated the interpretation quite practical. The average score of achievement (practicality) is obtained 85.96 with practical interpretation.

\section{Instrument Effectiveness}

Table 6. One-Sample Statistics

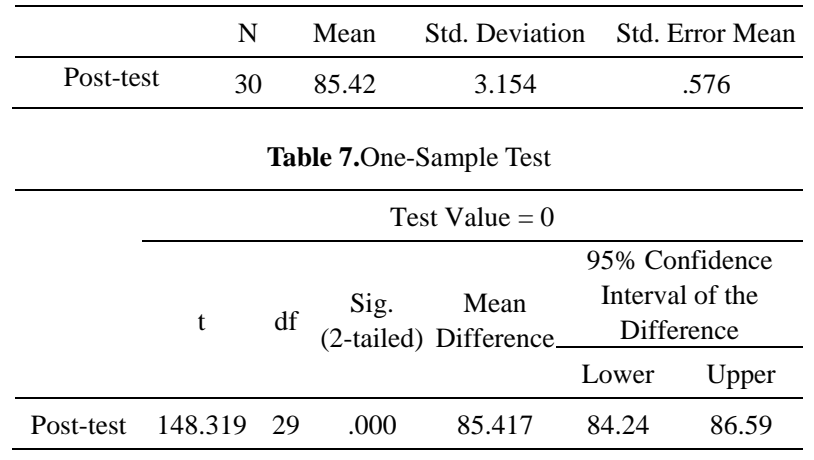

Based on the table above, the average value was found to be 85.42 with a standard deviation of 4745 exceeding the estimated average value (value of 80 ). The $t$ value is 148,319 while the $\mathrm{t}$-table value is $\mathrm{df}(\mathrm{n}-1)=29$ with alpha $0.075=2.04$. Thus it can be interpreted that the value of $t$ arithmetic $>$ from $t$ table $(148,319>2.04)$ with the conclusion of $\mathrm{H} 1$ which says the Physical Education teacher competency test instrument of a value of 80 is acceptable.

\section{Discussion}

From the various analyzes conducted, it was obtained that the standard instrument of teacher competency test (UKG) for Physical Education of secondary education was produced. The results consists of four domains namely (1) pedagogical competence has 53 items, (2) professional competence has 54 items, (3) personality competence has 44 statement items, and (4) social competence has 29 statements . The use of the four basic competency domains of the classes has also been tested in practicality with an average achievement of 85.42 and effectiveness with an average achievement of use of 85.96 (practical). Thus, in the development of this instrument, all valid methods have been developed to make the teacher's basic competency instruments, as well as make an assessment of the competencies possessed for his work (Missaghi-Wedefalk, Lindh, Schön-Ohlsson, \&Willén, 2012).

The results of previous studies by Weber, Marie (1977) carried out the same rare steps to create teacher competency test instruments on professional competence. The teacher competency test instrument can show teacher competencies related to student learning outcomes (Vogt\&Rogalla, 2009). The teacher competency test instrument is the basis for describing teacher quality. In contrast to potential tests, competency assessments must photograph the behavior of the samples displayed in work situations. The Teacher and Lecturer Law requires 4 competencies that must be possessed by teachers, namely pedagogical competencies, professional competencies, personal competencies, and social competencies. However, the Indonesian government only tests pedagogic and professional competence (Andina, 2018).

In addition, teacher competency test instruments are used only to measure mastery and professional mastery of teacher competencies in all subject matter and all levels of schools in Indonesia (Bakri\& Budi Raharjo, 2015; Sumaryanta, Mardapi, Sugiman, \&Herawan, 2018). This means that the teacher competency test instrument used in Indonesia only tests two competencies, namely; pedagogic competence and professional competence.

Achievement of teacher competency goals stated by the government is a greater competence and accountability. Therefore, the teacher competency test instrument truly tests the four teacher's competencies, with instruments that have ecological and consequential validity (Portelli, Solomon, Barrett, \&Mujawamariya, 2005). Therefore, it is necessary to have a teacher's personality and social competency test instrument, to complete the four teacher's basic competency tests beforehand. Some analysis show that the personality and social competence of a teacher has a real impact on student achievement (Corcoran \&Tormey, 2010). 


\section{Conclusions}

Based on our research, this is the first study that produces a standardized test instrument that can be used to test the four Physical Education teacher's competencies, namely Pedagogic competencies, Professional Competencies, Personality competencies, and Social competencies. This instrument has been tested practically and effectively in testing the competency of High School Physical Education teachers.

\section{REFERENCES}

[1] Andina, E. (2018). Efektivitas Pengukuran Kompetensi Guru. Jurnal Aspirasi. https://doi.org/https://doi.org/10.222 12/aspirasi.v7i1.1084

[2] Aqtash, S., Robb, W. F., Hunter, L. H., Almuhtasib, M., Hamad, A., \& Brownie, S. M. (2017). Self-Assessed Competence of Experienced Expatriate Nurses in a Rural and Remote Setting. SAGE Open Nursing. https://doi.org/10.1177/2377960817702382

[3] Arifin, M. A., Rasdi, R. M., Anuar, M. A. M., \& Omar, M. K. (2018). Competencies of Vocational Teacher: A Personnel Measurement Framework. International Journal of Academic Research in Business and Social Sciences. https://doi.org/10.6007/ijarbss/v7-i14/3659

[4] Bakri, F., \& Budi Raharjo, S. (2015). Analisis Hasil Uji Kompetensi Guru Fisika. Jurnal Penelitian \& Pengembangan Pendidikan Fisika. https://doi.org/10.21009/1.01113

[5] Boyatzis, R. E. (1982). Competence and job performance. Competence and Performance. https://doi.org/Samsung/Academico/Material Didatico MKZ/GC

[6] Corcoran, R., \&Tormey, R. (2010). Teacher education, emotional competencies and development education. Procedia - Social and Behavioral Sciences. https://doi.org/10.1016/j.sbspro.2010.03.352

[7] Cumberland, D. M., Herd, A., Alagaraja, M., \&Kerrick, S. A. (2016). Assessment and Development of Global Leadership Competencies in the Workplace: A Review of Literature. Advances in Developing Human Resources. https://doi.org/10.1177/1523422316645883

[8] Cury, S. P., Arias Astray, A., \& Palacios Gómez, J. L. (2019). Content validity analysis of ISD-1: an instrument for social diagnosis in care homes for older persons $\dagger$. European Journal of Social Work. https://doi.org/10.1080/13691457.2017.1364705

[9] Diep, P. C., \& Hartmann, M. (2016). Green Skills in Vocational Teacher Education - a model of pedagogical competence for a world of sustainable development. TVET @ Asia@Asia. https://doi.org/10.1002/ISSN

[10] Education, N. S. A. A. in H., \& International, A. C. S. E. (2015). Professional Competency Areas for Student Affairs Practitioners. Acpa, Naspa.
[11] George, D., \&Mallery, P., George, D., \&Mallery, P. (2003). SPSS for Windows step by step: A simple guide and reference. 11.0 update (4th ed.). Boston: Allyn \& Bacon. In BrJHaematol.

[12] Greenstein, L. (2012). Assessing 21st century skills: A guide to evaluating mastery and authentic learning. Assessing 21st Century Skills: A Guide to Evaluating Mastery and Authentic Learning.

[13] Grollmann, P. (2008). Professional competence as a benchmark for a European space of vocational education and training. Journal of European Industrial Training. https://doi.org/10.1108/03090590810861686

[14] Gudmundsdottir, S., \& Shulman, L. (1987). Pedagogical Content Knowledge in Social Studies. Scandinavian Journal of Educational Research. https://doi.org/10.1080/0031383870310201

[15] Hasril Amiruddin, M. (2015). Application of Communication Skills (CS) Among Lecturer on Vocational Teaching and Learning in Vocational College Zone Johor, Malaysia. International Journal of Vocational Education and Training Research. https://doi.org/10.11648/j.ijvetr.20 150104.11

[16] Kane, M. T. (2013). Validating the Interpretations and Uses of Test Scores. Journal of Educational Measurement. https://doi.org/10.1111/jedm.12000

[17] Loewenberg Ball, D., Thames, M. H., \& Phelps, G. (2008). Content knowledge for teaching: What makes it special? Journal of Teacher Education. https://doi.org/10.1177/0022487108324554

[18] Missaghi-Wedefalk, M., Lindh, M., Schön-Ohlsson, C., \&Willén, C. (2012). Further methodological development of the Test Instrument for Profile of Physical Ability (TIPPA) designed for patients with long-term musculoskeletal pain. Advances in Physiotherapy. https://doi.org/10.3109/14038196.2012.694907

[19] Nunnally, J. C. (1978). Phychometric theory. Psychometric Theory.

[20] Oluwasola, A. J. (2014). Professional Competence of Technical Teachers: A Factor Analysis of the Training Needs of Technical College Teachers. American Journal of Science and Technology American Journal of Science and Technology.

[21] Ovens, A., Hopper, T., \& Butler, J. (2013). Complexity thinking in physical education: Reframing curriculum, pedagogy and research. In Complexity Thinking in Physical Education: Reframing Curriculum, Pedagogy and Research. https://doi.org/10.4324/9780203126455

[22] Pantić, N., \&Wubbels, T. (2010). Teacher competencies as a basis for teacher education - Views of Serbian teachers and teacher educators. Teaching and Teacher Education. https://doi.org/10.1016/j.tate.2009.10.005

[23] PermendikbudNo57tahun2012-UjiKompetensiGuru.pdf. (n.d.).

[24] Portelli, J. P., Solomon, R. P., Barrett, S., \& Mujawamariya, D. (2005). Standardized teacher testing fails excellence and validity tests. Teaching Education. https://doi.org/10.1080/10476210500345482 
[25] Salyakhova, G. I., \&Valeeva, R. A. (2015). Pedagogical stimulation of university students' social competence development by means of interdisciplinary integration. Review of European Studies. https://doi.org/10.5539/res.v7n5p186

[26] Spöttl, G., \& Becker, M. (2016). Standards-an instrument to enhance the quality of TVET teacher training. TVET@sia The Online Journall for Technical and Vocational Education and Training in Asia.

[27] Stoof, A., Martens, R. L., Van Merriënboer, J. J. G., \&Bastiaens, T. J. (2002). The Boundary Approach of Competence: A Constructivist Aid for Understanding and Using the Concept of Competence. Human Resource Development Review. https://doi.org/10.1177/1534484302 013005

[28] Sumaryanta, Mardapi, D., Sugiman, \&Herawan, T. (2018). Assessing Teacher Competence and Its Follow-up to Support Professional Development Sustainability. Journal of Teacher Education for Sustainability. https://doi.org/10.2478/jtes-2018-0007

[29] Tigelaar, D. E. H., Dolmans, D. H. J. M., Wolfhagen, I. H. A. P., \& Van Der Vleuten, C. P. M. (2004). The development and validation of a framework for teaching competencies in higher education. Higher Education. https://doi.org/10.1023/B:HIGH.0000034318.74275.e4

[30] Varma, S. (2006). Preliminary item statistics using point-biserial correlation and p-values. Educational Data Systems.

[31] Vogt, F., \&Rogalla, M. (2009). Developing Adaptive Teaching Competency through coaching. Teaching and Teacher Education. https://doi.org/10.1016/j.tate.2009.04.0 02

[32] Waters, E., \&Sroufe, L. A. (1983). Social competence as a developmental construct. Developmental Review. https://doi.org/10.1016/0273-2297(83)90010-2

[33] Weber, M. (1977).Physical education teacher role identification instrument. Research Quarterly. American Alliance for Health, Physical Education and Recreation, 48(2), 445-451.

[34] Yusof, Y., Roddin, R., \&Awang, H. (2015). What Students Need, and What Teacher Did: The Impact of Teacher's Teaching Approaches to the Development of Students' Generic Competences. Procedia - Social and Behavioral Sciences. https://doi.org/10.1016/j.sbspro.2015.08.107 